UDC 005.322:316.46

JEL Classification: D70

http://doi.org/10.21272/mmi.2018.4-02

Stanislav Galic,

Komunala Novo mesto d.o.o., Slovenia

Sameer Mohammed Majed Dandan,

Ph.D., Northern Border University, Kingdom of Saudi Arabia

Annmarie Gorenc Zoran,

Ph.D., Faculty of Organisation Studies Novo mesto, Slovenia

\title{
INTUITIVE DECISION-MAKING INSIDE PUBLIC UTILITY ORGANIZATIONS IN SLOVENIA
}

Abstract. This study examined to what extent managers in Slovenian public utility organizations implement intuition into their decision-making process. Study aimed to determine whether there is a statistically significant link between emotional intelligence and the implementation of intuition in the decision-making process of managers in public utility organizations and focused primarily on emotional competencies, or more precisely, on emotional intelligence and intuition and if any statistically significant differences will be determined of intuition among managers and level of education. Aims of the article: to determine whether there is a statistically significant link between emotional intelligence and the implementation of intuition in the decision-making process of managers in public utility organizations. The bases for the theoretical background were a systematic overview and a critical analysis of the literature from the study field. According to the findings from the literature study, links were developed between the study areas and a hypothesis of the relationship between competencies, emotional intelligence and intuitive decisionmaking of managers formed. The study used a questionnaire as a measuring instrument, divided into 6 sets. (1) demographic data, (2) emotional intelligence (ESCQ), (3) intuitive potential, (4) use of intuition in decision making, (5) intuitive synthesis, (6) environmental scale and they were distributed among (110) respondents. Unsolved issues: the research in public utility companies should be conducted on a larger sample of respondents. The respondents in the research often base important decisions on intuition (81.7\%). The connection between emotional intelligence and implementation of intuition in the decision-making process was determined. A higher level of formal education is associated with rational decision making - that is, the higher the formal education is, the more rationally and nonintuitively decisions were made. The research was conducted in public utility organizations in Slovenia and it would be beneficial to conduct similar studies in other international public utility organizations, on the basis of which comparisons could be made.

Keywords: emotional intelligence, intuition, public administration, competences, utility company, decision-making process, successfulness.

Introduction. Utility companies are definitely one of the most important industries in the public sector, the task of which is to produce and maintain the basic material conditions of life in settlements and cities. Due to the growth of communities, cities and the number of inhabitants, the increasing demands for costcutting, the satisfying of different stakeholders, the quality of services and the rational use of resources, the operation and management of utility companies are becoming increasingly more complex. The constant changes, adaptation to the market, economic and political problems and challenges in today's world of management, both in private as well as in public sectors, demand different leadership and appropriately developed competencies of the managers for the successful and efficient performance of their functions. The professional literature and researches on leadership mostly focus on factors that determine the success of leadership, that is, the characteristics and competencies of managers, leadership styles and behaviour. Intelligence, education and analytical thinking are thus not sufficient anymore for facing the challenges of a competitive environment and to ensure the long-term success of organizations and companies. There is more and more emphasis on multiple intelligences and the construct of emotional intelligence. The increase of theories and studies that emphasize that traditional

Cite as: Galic, S., Dandan, S. M. M, \& Zoran, A. G. (2018). Intuitive Decision-Making inside Public Utility Organizations in Slovenia. Marketing and Management of Innovations, 4, 14-25. http://doi.org/10.21272/mmi.2018.4-02 
rational decision-making is not sufficient anymore for achieving the most effective results places at the core of the study of management psychology and leadership also the notion of intuition as a competence of managers. The professional literature classifies intuition under data processing that differs from the analytical or rational process. At the strategic level of decision-making, the intuition is particularly important when the decision-makers are forced to solve individual, unstructured and complex problems. The research question deals with the extent to which the managers in Slovenian utility companies implement intuition into their decision-making process. The research focuses on the emotional competencies, more precisely, on the emotional intelligence and intuition, at which point the connection between the emotional intelligence and the use of intuition of managers in Slovenian utility companies, that is, managers in the public sector, will be determined. The purpose and aim of the research are to determine whether there is a statistically significant connection between the emotional intelligence and the implementation of intuition in the decision-making process of managers in utility companies in Slovenia. We also want to determine whether there are statistically significant differences in the use of intuition among managers in utility companies in Slovenia due to the level of education.

Theoretical starting points. One of the key characteristics of a manager is the sovereign decisionmaking. The ability to quickly and correctly make business decisions is connected to the characteristics and self-image of the manager, his competencies, knowledge of the mission of the organization or company, and the set objectives that the manager or the organization want to achieve. According to the classic economic model of decision-making, decisions are the result of an analytical, purposeful and rational process of decision-making, where individuals during the process develop all possible alternatives, collect and take into account the relevant facts of each possibility, calculate the expected returns of each alternative and choose the optimal option (Čadež, 2013, p. 26). However, an individual is not an exclusively rational machine, which would analyse and find the best alternative, but rather often also makes a decision that is satisfactory. As it is extremely difficult to recognize all the relevant facts and to develop all the possible alternatives, managers often rely on their knowledge, experience and intuition. The implementation of intuition in the operation often complements the ability of managers to effectively perform tasks and helps the managing of different situations. According to Thornton (2013), successful managers believe that individuals and organizations have unique talents and thus represent unexploited resources. Managers strive to discover and encourage the potentials of their followers so that they can achieve an ever-higher level. The foundation of successful leadership certainly also includes competencies that are characteristic of managers. As can be observed, in defining a management process, authors include different constructs in their research and some rely more on some, others on others. Kohont and Faganelj (2016, p. 48) also emphasize the importance of competences; they describe leadership as a process with which managers, on the basis of their own competencies, direct their colleagues towards the agreed goals, using different theories or forms and various methods or styles. Competencies are classified on the basis of different aspects, while their design depends on the field in which an individual works. Competence, therefore, cannot be assessed in general, as they refer to a large extent to the specific work or situation. Kohont (2016b, p. 7) defines competencies by applying them to an individual, then dividing them according to the dimension and defining their components. A more detailed division is shown in Figure 1.

Different references deal with the competences of managers and leaders at the same time and in most cases, they designate them with the common term "managerial competencies". More and more attention is being paid to managerial competencies, and the massive emphasis on them dates back to 1982 with the founder Boyatzits and his work "The competent manager" (Boyatsiz, 1982). Boyatzis, Goleman and Rhee $(2000$, p. 357) defined the following competencies specific to successful managers and leaders: proactivity, self-confidence, performance orientation, communication skills, inductive reasoning and creativity, interest in influencing others, diagnostic use concepts and deductive reasoning, use of social 
power and control of group processes.

\section{CLASSIFICATION OF COMPETENCES}

\begin{tabular}{|l|}
\hline \multicolumn{1}{|c|}{ INDIVIDUAL } \\
\hline \\
\hline - Key/basic/generic \\
- Work-specific \\
- Organizational- \\
specific \\
- Managerial \\
\hline
\end{tabular}

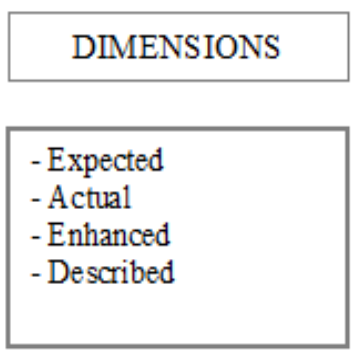

COMPONENTS

- Knowledge

- Skills

- Characteristics

- Motives

- Self-esteem

Figure 1 - Classification of competences

Sources: adapted from the Multiplicity and Usefulness of Competences (p.7), A. Kohent (2016).

On the basis of their studies, Dulewics and Higgs (2003, p. 76) proposed 15 managerial competencies and divided them into three groups:

- intellectual competences (vision and imagination, critical analysis and judgment, strategic insight);

- managerial competencies (communication, resource management, empowerment, ability to develop and goal-orientation);

- emotional competencies (self-awareness, emotional resistance, motivation, sensitivity, influence, intuition, conscientiousness).

Intellectual and managerial competencies have a long tradition in the theory of management and leadership, however, the importance of emotional competencies has been increasingly emphasized in the last few decades as being the quality of effective and successful leaders. The latest researches focused on the division of managerial competencies with respect to the operation of a particular sector. According to Jaloch, Krane, Ekambaram and Prawelska-Skrzypek (2014, p. 249), the similarities between the private and the public sector can be seen in their function, while the sectors differ according to the conditions and restrictions under which they must operate. The private sector is usually run by managers, whereas the public companies are under collective ownership or owned by political communities. According to the definition of managerial competencies, it is, therefore, necessary to separate the private and public sectors. In addition, as Wirick points out (2009, p. 247), the public sector project managers operate in an environment that is often not primarily result-oriented, but rather simply dedicated to complying with higher principles, at which point the interference of politics is continually present, which may be disruptive. Consequently, are the goals of management of public organizations less clear than in the case of private organizations, since management is based more on political processes and not according to the principles that would otherwise be chosen by the manager. Managers of public organizations must in their operations take into account primarily the ethics of public service and create the balance between the demands and expectations of different stakeholders, at which point it is necessary to stress precisely different policies. At the same time, according to Park and Word (2012, p. 721), it is characteristic of managers of public companies that their goals are less oriented to materialism compared to managers of private companies, as the former has a greater desire to serve the public. The specific role of the public sector is also evident in the Slovenian environment. Bavec and Pivljakovič (2007, p. 319) in their research found that Slovenian managers of public utility companies do not feel the need to compare themselves with the competition due to lack of competition and that their approach to the quality of services does not really reflect the true managerial challenge. The cause, according to the authors, is mainly reflected in the influence of politics 
and the local environment, which leads to the managers feeling impotent in making decisions in the company. Intuition, as a human ability of direct perception and understanding of the essence of something, irrespective of intelligent analysis, is used by every individual in decision making, however, only the rare few use it consciously. According to Sadler-Smith and Shefy (2004, p. 78), intuition is an evasive concept; it can be recognized but is extremely difficult to define and describe. Jedrzejczyk (2012, p. 19) also agrees with this statement and defines intuition as one of the human qualities, which is still not fully recognized. Carl Jung, one of the most influential researchers, identified intuition as a psychological function, characteristic of all people at different stages and one that is reflected in personality types. Intuition is for him an unconscious perception and understanding of the whole, a cognitive function beyond reason (Fields, 2001, p. 10). Jung claims that an intuitive person focuses on possibilities and devotes less attention to detail, and often finds solutions that are not based on facts (Anderson, 2000, p. 49). According to Jung (1946, p. 567-8), intuition thus has an interesting definition, as it is not perception, nor a feeling or an intellectual conclusion, but is a perceptual, irrational function. Jung's theory of psychological types is the basis for the development of the widely used Myers-Briggs (MBTI) type indicator, on which the AIM Survey (Agor Intuitive Management Survey) is based, which will be used for the purposes of this research. Goleman (2001, p. 338) defined emotional intelligence as the ability to recognize one's own emotions and emotions of other people, the art of managing emotions in ourselves and in relation to others.

According to Sadry (2012, page 535), the advocates of emotional intelligence believe that it can be even more important in determining the management's success than the intelligence quotient. Emotional intelligence consists of two concepts, namely the intelligence and emotions, which organizations in the past often treated with a hint of negativity and considered to be an indicator of weakness and poor selfcontrol. Nowadays we perceive emotions differently; according to Rajah, Song, and Arvey (2011, p. 1108) they are defined as intense and limited reactions to an event, are directed towards a specific goal and play an important role in the study of organizational behaviours and leadership. Several authors (Sosik \& Megerian, 1999; Reed-Woodard \& Clarke, 2000) found the correlation between emotional intelligence and intuition and argued that the effective use of emotional intelligence enables individuals to use intuition to a greater extent. The findings of Downey, Papageorgiou and Stough (2006, pp. 259-260) suggest that intuitive managers are to a greater extent emotionally more intelligent. The basis for the use of intuition is, above all, the ability to identify one's own emotions and emotional states, the ability to express inner feelings and include emotional knowledge in the decision-making process.

As the authors Bavec and Pivljakovič mentioned (2007, p. 331), when examining domestic literature, the lack of research in the structure of management and competencies of managers and leaders in public utility companies in Slovenia, in particular, detailed research on specific competence and its impact on business decision making, became obvious. Until now, the research into the competencies of emotional intelligence and intuition, their interconnections and the implementation of intuition in business decisions in utility companies in Slovenia has not yet been observed.

Method. The research focuses on emotional competencies, more precisely on emotional intelligence and intuition, with the intent of determining the connection between emotional intelligence and the use of intuition of managers in Slovenian utility companies, that is, managers in the public sector. The research was meant to confirm the following hypotheses:

- hypothesis 1: There is a statistically significant connection between emotional intelligence and implementation of intuition in the decision-making process of managers in utility companies in Slovenia;

- hypothesis 2: There are statistically significant differences in terms of education in the use of intuition among managers in utility companies in Slovenia.

The bases for the theoretical background were a systematic overview and a critical analysis of the literature from the study field. According to the findings from the literature study, links were developed between the study areas and a hypothesis of the relationship between competencies, emotional 
intelligence and intuitive decision-making of managers formed. The data, on the basis of which the connections and relationships were studied, are collected with the anonymous online survey $1 \mathrm{ka}$.si. With the quantitative method of the questionnaire, we investigated and analysed the extent to which managers in Slovenian utility companies implement intuition into their decision-making process.

The used measuring instrument is a questionnaire, divided into 6 sets: (1) demographic data, (2) emotional intelligence (ESCQ), (3) intuitive potential, (4) use of intuition in decision making, (5) intuitive synthesis, (6) environmental scale. The questionnaire uses the open and closed form of questions. Emotional intelligence was measured using the ESCQ (Skill and Competence Questionnaire) questionnaire, which covers 45 statements. The grading scale has 5-degrees, where 1 means "not at all" and 5 "always true". The level of emotional intelligence is then calculated on the basis of the total sum of responses. The ESCQ questionnaire was created in Croatia, in a similar cultural context as there is in Slovenia and is based on the theoretical basis of the Mayer-Salovey model of emotional intelligence as an ability (Takšić, Mohorić \& Duran, 2009, 7).

To measure the intuitive potential and the actual use of intuition in decision making, we used the AIM Survey (Agor Intuitive Management Survey), which is divided into two parts. In the first part, the instrument measures the intuitive potential, and in the second the use of intuition in decision-making. The AIM Survey is time-efficient and was developed on the basis of intuitive abilities of senior managers. The scale of intuitive synthesis and the environmental scale represent the fifth and sixth part of the established questionnaire and were developed as part of the research on intuitive processes in different profiles of companies (Khatri \& Ng, 2000, p. 57). The intuitive synthesis scale developed by the mentioned authors which measure the use of intuition by the managers was, for the purpose of the research, used as safety questions of the fourth set of the questionnaire (use of intuition in decision making).

The research includes the managers in utility companies in Slovenia, who occupy the following positions: director, business director, technical director, assistant director, head of sector and head of service. Due to the Law on Public Utilities (Official Gazette of the Republic of Slovenia, No. 32/93), the infrastructure for the provision of public utility services, which was financed primarily by public funds, became the property of municipalities. The former communal companies - there were 79 - changed their status into either private or public companies. The status of the public utility company was received by all communal companies in which the share of the social capital of a municipality or state is more than $50 \%$ (Hrovatin et al., 2002, 163-164; Virant, 2002, p. 155). For the purpose of determining the target population, all the companies that have the status of a public utility company were previously identified. According to the data obtained from the Register of Business Entities (AJPES) and the list of providers of public services for environmental protection (Ministry of the Environment and Spatial Planning) and taking into account the criterion on the share of social capital, there are 83 public utility companies in Slovenia.

The survey questionnaire was sent to 137 addresses, and we received 110 partially completed questionnaires and 93 fully completed questionnaires. For data processing, we used the software program SPSS (Statistical Program for Social Sciences). The basic characteristics are presented with descriptive statistics - frequency tables, arithmetic meanings and standard deviations. For the verification of hypothesis 1 , a regression analysis using the enter method was used, which is used to determine the linear causal relationships between the dependent and one or more independent variables. We were interested in the statistical significance and the strength of the relationship, and afterwards predicted the value of the dependent variable. With the analysis of the variance or ANOVA, we performed an experiment with which we checked the differences in the average value of the variable in several groups. To verify the hypothesis 2, we used Pearson's correlation coefficient, which is a measure of the relationship for the interval type of variables.

Results. A total of 110 respondents responded to the questionnaire, of which $64.5 \%$ were men and $35.5 \%$ were women. The majority of respondents are between 41 and 50 years old $(38.7 \%)$, a third of the 
respondents are between 51 to $60(34.4 \%)$, followed by the age group from 31 to 40 years $(18.3 \%)$. The number of respondents that are 61 years of age or over $(5.4 \%)$ and 18 to 30 years $(3.2 \%)$ is the lowest.

Most of the respondents have a university degree (35.5\%), followed by higher education and master's degree (20.4\%). $16.1 \%$ of the respondents have higher education, while $5.4 \%$ have the lowest level of education, that is secondary degree. Of all the respondents, only two are Doctors of Science $(2.2 \%)$.

From the structure in the workplace, it is evident that the majority of respondents are employed as managers $(31.2 \%)$, followed by sector managers $(24.7 \%)$, directors $(26.9 \%)$. A very small percentage of the respondents are technical directors $(7.5 \%)$, assistant directors $(5.4 \%)$, and the least of them are business directors $(4.3 \%)$.

The majority of those surveyed in utility companies have been employed for more than 21 years (26.9\%), followed by those employed from 1 to 5 years $(21.5 \%)$ and from 6 to 10 years $(21.5 \%)$. We got the least responses from those who have been in the company for less than 1 year (4.3\%).

On average, in most cases, the respondents estimated that the assertions applied to them. They mostly work with enthusiasm if someone praises them $(M=4.1)$, with perseverance, can solve problems that at first glance seem unsolvable $(M=4.0)$, they learn best when they are in a good mood and happy $(M=4.0)$, they mostly know a lot about their emotional state $(M=4.0)$ and most of them can describe their current emotional state $(M=4.0)$. On average, they do not show the person they do not like how they feel $(\mathrm{M}=2.9)$, and sometimes they cannot recognize what has happened to someone who feels bad $(M=3.2)$ (see Table 1).

Table 1 - Average values of emotional intelligence claims

\begin{tabular}{|c|c|c|}
\hline Paragraph & Mean & $\begin{array}{l}\text { Std. } \\
\text { Deviation }\end{array}$ \\
\hline 1 & 2 & 3 \\
\hline I can remain in a good mood even if something bad happens to me & 3.4 & 0.73 \\
\hline I can describe my feelings and emotions in words & 3.8 & 0.84 \\
\hline I can remain in a good mood even when people around me are in a bad one & 3.5 & 0.76 \\
\hline Unpleasant experiences teach me how to behave differently in the future & 4.0 & 0.73 \\
\hline When someone praises me, I work with more enthusiasm & 4.1 & 0.76 \\
\hline If I do not like something, I show it immediately & 3.4 & 0.77 \\
\hline If I do not like someone, I find a way to show that to them & 2.9 & 0.97 \\
\hline If I am in a good mood, it is hard to get me into a bad mood & 3.8 & 0.69 \\
\hline If I am in a good mood, every problem seems solvable & 4.0 & 0.65 \\
\hline $\begin{array}{l}\text { When I am in the company of a person who appreciates me, I pay attention to } \\
\text { how I behave }\end{array}$ & 3.8 & 0.92 \\
\hline I learn best when I am in a good mood & 4.0 & 0.78 \\
\hline If I really want and insist, I can solve a problem that at first glance seems unsolvable & 4.1 & 0.74 \\
\hline When I meet an acquaintance, I immediately notice what their mood is like & 3.7 & 0.71 \\
\hline When I see how someone feels, I usually know what happened to them & 3.2 & 0.75 \\
\hline I can recognize in a friend when they are sad and disappointed & 3.9 & 0.71 \\
\hline I can easily find a way to approach a person I like & 3.5 & 0.86 \\
\hline I can recognize the feelings that I experience at a certain moment & 3.8 & 0.69 \\
\hline I quickly detect mood changes in a friend & 3.9 & 0.70 \\
\hline I can easily think of a way to cheer my friends for their birthdays & 3.7 & 0.81 \\
\hline I can quickly convince a friend that there is no reason to worry & 3.6 & 0.69 \\
\hline I can express my feelings well & 3.7 & 0.88 \\
\hline I can recognize most of my feelings & 3.9 & 0.79 \\
\hline I can describe my current emotional state & 4.0 & 0.72 \\
\hline I can say that I know a lot about my emotional state & 4.0 & 0.72 \\
\hline
\end{tabular}


Table 1

\begin{tabular}{|c|c|c|}
\hline 1 & 2 & 3 \\
\hline When observing a person in society, I can accurately determine their feelings & 3.5 & 0.62 \\
\hline I notice if someone feels uncomfortable & 3.8 & 0.68 \\
\hline My behaviour is a reflection of my inner feelings & 3.5 & 0.89 \\
\hline People can easily recognize my mood & 3.3 & 0.78 \\
\hline I try to control the unpleasant emotions and strengthen the positive ones & 3.9 & 0.76 \\
\hline There is nothing wrong with how I usually feel & 3.8 & 0.70 \\
\hline I do the obligations and tasks as soon as possible, instead of thinking about them & 3.7 & 0.85 \\
\hline I usually understand why I feel bad & 3.8 & 0.70 \\
\hline I try to stay in a good mood & 3.9 & 0.77 \\
\hline I can recognize the feelings of others by the expression on their face & 3.7 & 0.62 \\
\hline I can identify covert jealousy in my friends & 3.5 & 0.76 \\
\hline I notice if someone is trying to hide a bad mood & 3.5 & 0.74 \\
\hline I notice if someone has a bad conscience & 3.4 & 0.69 \\
\hline I notice if someone is trying to hide their true feelings & 3.4 & 0.64 \\
\hline I notice if someone is bitter & 3.7 & 0.76 \\
\hline As far as I am concerned, it is okay to feel like I am feeling at the moment & 3.8 & 0.75 \\
\hline I can easily express sympathy towards a person of the opposite sex & 3.5 & 0.84 \\
\hline I notice if someone behaves differently than they feel & 3.5 & 0.74 \\
\hline I can easily list most of my feelings & 3.8 & 0.80 \\
\hline I can express how I feel & 3.9 & 0.72 \\
\hline I know how to nicely surprise each of my friends & 3.7 & 0.80 \\
\hline
\end{tabular}

Sources: the authors' development

The research question raises the inquiry about the extent to which the employees in utility companies use intuition in decision-making. Almost two thirds $(81.7 \%)$ of the respondents confirmed that they use intuition. Of those who have confirmed that they use intuition in decision-making they mostly use it in situations where there are choices of several possible alternative choices with good arguments and evidence $(26.2 \%)$. They use intuition a bit less when there is a high degree of uncertainty $(22.9 \%)$ and there are few precedents $(22.9 \%)$. The least of the respondents use intuition in situations where the variables are less scientifically predictable, or the knowledge of the facts is limited ( $8.2 \%)$. When they feel that a decision is correct, they mostly feel peace or calm (48.5\%), and the least sudden insight $(8.1 \%)$. When they feel that things are going in the wrong direction and it would be better to postpone the decision for a while, most of the respondents felt anxiety $(40.2 \%)$. A smaller percentage of the respondents $(0.7 \%)$ claimed that they feel confusion, uncertainty, discomfort or reactions of the body. Most of the respondents believe that stress is what has most often blurred the use of intuition in making important decisions, while they deny the lack of self-confidence $(13.2 \%)$. We find that most of the respondents $(75.3 \%)$ do not use any specific methods that would facilitate the effective use of intuition, and they mostly do not use any special techniques for developing intuitive abilities (80.6\%) (See Table 2).

Table 2 - Measurement of actual use of intuition in decision-making

\begin{tabular}{|l|c|c|}
\hline \multicolumn{1}{|c|}{ Questions } & Answers & Share (\%) \\
\hline \multicolumn{1}{|c|}{1} & 2 & 3 \\
\hline $\begin{array}{l}\text { Do you think that you use intuition to make } \\
\text { some of the most important decisions }\end{array}$ & Yes & 81,7 \\
\hline $\begin{array}{l}\text { If yes, in which situations do you use } \\
\text { intuition to make decisions? }\end{array}$ & No & 18,3 \\
\hline & Where there is a high degree of uncertainty. & 22,9 \\
\hline & Where there are few precedents. & 22,9 \\
\hline
\end{tabular}


Table 2

\begin{tabular}{|c|c|c|}
\hline 1 & 2 & 3 \\
\hline & $\begin{array}{l}\text { Where the variables are less scientifically } \\
\text { predictable and the knowledge of the facts is } \\
\text { limited. }\end{array}$ & 8,2 \\
\hline & $\begin{array}{l}\text { Where there is the choice of several possible } \\
\text { alternatives with good arguments and evidence. }\end{array}$ & 26,2 \\
\hline & $\begin{array}{l}\text { Where there is a high degree of pressure and the } \\
\text { time is limited. }\end{array}$ & 19,2 \\
\hline & Other: & 0,6 \\
\hline $\begin{array}{l}\text { What do you feel when you "know" that a } \\
\text { certain decision is "correct"? What signs } \\
\text { do you rely on? }\end{array}$ & Excitement & 10,3 \\
\hline \multirow{6}{*}{$\begin{array}{l}\text { What feelings or signals do you experience } \\
\text { when you "know" that things are going } \\
\text { wrong and it would be better to postpone } \\
\text { the decision for some time? }\end{array}$} & Warmth & 11,8 \\
\hline & Peace/Calm & 48,5 \\
\hline & Vigour & 20,6 \\
\hline & Sudden insight & 8,1 \\
\hline & Other: & 0,7 \\
\hline & Anxiety & 40,2 \\
\hline \multirow{5}{*}{$\begin{array}{l}\text { Which of the following circumstances has } \\
\text { blurred the use of intuition in making } \\
\text { important decisions? }\end{array}$} & Upset stomach & 20,5 \\
\hline & Mixed and ambivalent signals & 35,9 \\
\hline & Other: & 3,4 \\
\hline & Anger & 15,1 \\
\hline & Stress & 33,6 \\
\hline \multirow{6}{*}{$\begin{array}{l}\text { Do you hide the use of intuition others or } \\
\text { share it with them? }\end{array}$} & Too big an ego & 11,8 \\
\hline & Rashness & 25,7 \\
\hline & Lack of confidence & 13,2 \\
\hline & Other: & 0,6 \\
\hline & from I keep the use of intuition a secret & 32,3 \\
\hline & I share the use of intuition with others & 67,7 \\
\hline \multirow{2}{*}{$\begin{array}{l}\text { When using intuition in making decisions, } \\
\text { where do you think this works best? }\end{array}$} & $\begin{array}{l}\text { At the beginning when I try to estimate the future } \\
\text { available options }\end{array}$ & 60,2 \\
\hline & $\begin{array}{l}\text { In the end when I try to judge and evaluate all } \\
\text { available information }\end{array}$ & 39,8 \\
\hline \multirow{2}{*}{$\begin{array}{l}\text { Do you use any specific methods or } \\
\text { techniques to make the use of your } \\
\text { intuition more effective? }\end{array}$} & $\begin{array}{l}\text { Yes. } \\
\end{array}$ & 24,7 \\
\hline & No. & 75,3 \\
\hline \multirow{2}{*}{$\begin{array}{l}\text { Do you use any particular method or } \\
\text { technique to develop your intuitive skills? }\end{array}$} & Yes. & 19,4 \\
\hline & No. & 80,6 \\
\hline
\end{tabular}

Sources: the authors' development

In order to check whether emotional intelligence has an influence on the implementation of intuition in the decision-making process of managers in utility companies in Slovenia, we used the regression analysis with the enter method. For the dependent variable we considered the emotional intelligence factor and for the independent variables all the variables for the use of intuition in decision-making (the scale of intuitive synthesis), which are evident from Table 3.

On the basis of the performed regression according to the enter method, the results suggest that only $17.4 \%$ of the variance of the dependent variable is explained with the independent variables, with the value of the determination coefficient R2 equal to 0.174 (see Table 4).

The independent variable for the use of intuition "as a manager I rely on my past experience when 
making important decisions" shows the statistical significance of the importance of the influence on the dependent variable $(\mathrm{Sig} .=0,025)$ and with the highest standardized $\beta=0,295$ and non-standardized $(B=0,212)$ influence.

Table 3 - Analysis of the main components for the use of intuition in decision-making (scale of intuitive synthesis)

\begin{tabular}{|l|c|}
\hline & Component \\
\hline As a manager, I rely on clear judgment when making important decisions. & 0.889 \\
\hline As a manager, I rely on my past experience when making important decisions. & 0.897 \\
\hline $\begin{array}{l}\text { As a manager, I often do not have enough information when making a decision and } \\
\text { therefore rely on the "sixth sense". }\end{array}$ & 0.321 \\
\hline
\end{tabular}

Sources: the authors' development

Table 4 - Regression using the enter method for hypothesis 1

\begin{tabular}{|c|c|c|c|c|}
\hline Model & $\mathbf{R}$ & $\mathbf{R}$ Square & Adjusted R Square & Std. Error of the Estimate \\
\hline 1 & 0,417 & 0,174 & 0,146 & 0,924 \\
\hline
\end{tabular}

Sources: the authors' development

The $F$ value of the model is not negligible $(6,262)$ and is statistically significant $(0,001)$, which suggests that there is some relationship between the variances of the variables involved (see Table 5).

Table 5 - ANOVA using the enter method for hypothesis 1

\begin{tabular}{|c|c|c|c|c|c|c|}
\hline \multicolumn{2}{|c|}{ Model } & Sum of Squares & df & Mean Square & F & Sig. \\
\hline \multirow{3}{*}{1} & Regression & 16,034 & 3 & 5,345 & 6,262 & 0,001 \\
\cline { 2 - 7 } & Residual & 75,966 & 89 & 0,854 & & \\
\cline { 2 - 7 } & Total & 92,000 & 92 & & & \\
\hline
\end{tabular}

Sources: the authors' development

The other two independent variables, which are "When making important decision as a manager I often do not have enough information and therefore rely on the "sixth sense" and "As a manager I rely on clear judgment when making important decisions" do not show a statistically significant influence on the dependent variable (see Table 6).

Table 6 - Determination of the statistical characteristics of the influence of the independent variable on the dependent variable

\begin{tabular}{|l|c|c|c|c|c|}
\hline \multicolumn{4}{|c|}{ Unstandardized Coefficients } & \multicolumn{3}{c|}{ Standardized Coefficients } \\
\hline & $-1,555$ & Std. error & Beta & t & Sig \\
\hline (Constant) & 0,132 & 0,103 & 0,164 & 1,279 & 0,204 \\
\hline $\begin{array}{l}\text { As a manager, I rely on clear judgment when } \\
\text { making important decisions. }\end{array}$ & 0,212 & 0,092 & 0,295 & 2,333 & 0,023 \\
\hline $\begin{array}{l}\text { As a manager, I rely on my past experience when } \\
\text { making important decisions. }\end{array}$ & $-0,055$ & 0.065 & $-0,082$ & $-0,846$ & 0,400 \\
\hline $\begin{array}{l}\text { When making the important decision as a } \\
\text { manager I often do not have enough information } \\
\text { and therefore rely on the "Sixth sense". }\end{array}$ & & & & \\
\hline
\end{tabular}

Sources: the authors' development

To determine whether there are statistically significant differences in terms of education in the use of 
intuition among managers in utility companies, we used the Pearson's correlation test, which showed a statistically insignificant $($ Sig. $=0,309)$ negative, barely perceivable relationship between the level of education and the use of intuition (rxy $=0.107)$. Based on the results of the correlation test, we can conclude that there is no relationship between the level of education and the use of intuition among managers in utility companies.

Table 7 - Pearson's correlation test between the level of education and the use of intuition

\begin{tabular}{|l|l|c|c|}
\hline & & Factor use of intuition & Education \\
\hline Factor use of intuition & Pearson's correlation & 1 & -0.107 \\
\hline & Sig. (2-tailed) & & 0.309 \\
\hline & $\mathrm{N}$ & 93 & 93 \\
\hline Education & Pearson's correlation & -0.107 & 1 \\
\hline & Sig. (2-tailed) & 0.309 & 93 \\
\hline & $\mathrm{N}$ & 93 & \\
\hline
\end{tabular}

Sources: the authors' development

Conclusions. With the research question, we were interested in the extent to which employees in utility companies use intuition in decision-making. Almost two thirds (81.7\%) of the respondents confirmed that they use intuition when making a decision. Those who have confirmed that they use intuition in decision-making mostly use it in situations where there several possible alternative choices with good arguments and evidence (26.2\%). Fewer of them use it when there is a high degree of uncertainty $(22.9 \%)$ and there are few precedents $(22.9 \%)$. The least of the respondents use intuition in situations where the variables are less scientifically predictable, or the knowledge of the facts is limited (8.2\%). When they feel that a decision is correct, they mostly feel peace or calm $(48.5 \%)$, and the least sudden insight $(8.1 \%)$. When they feel that things are going in the wrong direction and it would be better to postpone the decision for a while, most of the respondents feel anxiety $(40.2 \%)$. We find that most of the respondents $(75.3 \%)$ do not use any specific methods that would facilitate the effective use of intuition, and they mostly do not use any special techniques for developing intuitive abilities (80.6\%) (See Table 2). Several authors (Sosik \& Megerian, 1999; Reed-Woodard \& Clarke, 2000) found the correlation between emotional intelligence and intuition and argued that the effective use of emotional intelligence enables individuals to use intuition to a larger extent. The findings of Downey, Papageorgiou \& Stough (2006, p. 259-260) suggest that intuitive managers are to a larger extent emotionally more intelligent. The basis for the use of intuition is, above all, the ability to identify one's own emotions and emotional states, the ability to express inner feelings and incorporate emotional knowledge in the decision-making process. With hypothesis 1 we tried to establish the relationship between emotional intelligence and the use of intuition of managers in Slovenian utility companies. Given that ANOVA demonstrates the statistical characteristic of the regression model and the statement "As a manager, I rely on my past experience when making important decisions" shows the statistical significance of the importance of the influence on the dependent variable, the hypothesis is confirmed. Bulog (2016, pp. 395-396) argues that the level of education should reflect the individual's knowledge, skills and abilities. At the same time, he also notes that a higher level of formal education is often associated with rational decision-making. We tried to establish whether there are statistically significant differences in terms of education with regards to the use of intuition between managers in utility companies in Slovenia. On the basis of the obtained results, we reject the second hypothesis and confirm the finding of Bulog (2016, pp. 395-396) that a higher level of formal education is associated with rational decision-making - that is, the higher the formal education, more rationally, nonintuitively we make decisions. The results of the research showed that employees, when making an important decision, mostly use intuition (81.7\%). They use it in most situations where there are more possible alternative choices with good arguments and evidence, as well as when there is a high level of 
uncertainty and there are few precedents. The smallest number of the respondents uses intuition in situations where the variables are less scientifically predictable, or the knowledge of the facts is limited. When they feel that a decision is correct, they mostly feel peace or calm. When they feel that things are going in the wrong direction and it would be better to postpone the decision for a while, most of the respondents feel anxiety. Stress has proven to cause a blur in the use of intuition in making important decisions, while the lack of self-confidence does not affect the use of intuition. We find that most of the respondents do not use any specific methods that would facilitate the effective use of intuition, and they mostly do not use any special techniques for developing intuitive abilities. Based on the findings, we conclude that training in the development of intuition with special methods could further increase the use of intuition in decision-making. On the basis of the verified hypotheses, we found that there is a connection between emotional intelligence and the use of intuition of managers in Slovenian utility companies. The results show the statistical significance of the regression model, and the claims for the use of intuition in the decision-making process show a statistically significant importance of the influence on the dependent variable. We, therefore, conclude that emotional intelligence influences the intuitive decision-making of managers in public utility organizations in Slovenia. We tried to determine whether there are statistically significant differences in terms of education in the use of intuition between managers in public utility companies in Slovenia. On the basis of the obtained results, we rejected the hypothesis and confirmed the finding of Bulog (2016, p. 395-396), who claims that a higher level of formal education is associated with rational decision-making, that is, the higher the formal education, more rationally, non-intuitively we make decisions. This research study represents a contribution to the field of management of public utility companies and provides a starting point for further in-depth research in this area. The research was conducted in public utility organizations in Slovenia and it would be beneficial to conduct similar studies in other international public utility organizations, on the basis of which comparisons could be made. Above all, the research in public utility companies should be conducted on a larger sample of respondents.

\section{References}

Anderson, J. A. (2000). Intuition in managers: Are intuitive managers more effective? Journal of Managerial Psychology, 15(1), 46-63. doi: 10.1108/02683940010305298

Bavec, C., \& Pivljakovič, B. (2007). Posebnosti managemeneta javnih komunalnih podjetji v Sloveniji. Univerza na Primorskem: Fakulteta za management. 2(4): 319-332.

Bavec, C., \& Pivljakovič, B. (2007). Posebnosti managemeneta javnih komunalnih podjetji v Sloveniji. Univerza na Primorskem: Fakulteta za management. 2(4): 319-332.

Boyatzis, R. E. (1982). The competent manager: A model for effective performance. New Jersey: John Wiley \& Sons.

Boyatzis, R. E., Goleman, D., \& Rhee, K. (2000). Clustering competence in emotional intelligence: Insights from the emotional competence inventory. Emotional intelligence 2(3): 343-362.

Čadež, S. (2013). Temelji poslovodnega računovodstva. Ljubljana: Ekonomska fakulteta.

Downey, L. A., Papageorgiou, V. \& Strough, C. (2006). Examining the relationship between leadership, emotional intelligence and intuition in senior female managers. Leadership \& Organization Development Journal 27(4), 250-264. doi: $10.1108 / 01437730610666019$

Dulewicz, V., \& Higgs, M. J. (2003). Design of a new instrument to assess leadership dimensions and styles. UK: Henley Management College.

Fields A. F. (2001). A Study of Intuition in Decision-Making using Organizational Engineering Methodology (Dissertatuon). Wayne Huizenga Graduate School of Business and Entrepreneurship of Nova Southeastern University.

Goleman, D. (2001). Čustvena inteligenca na delovnem mestu. Ljubljana: Mladinska knjiga.

Hrovatin, N., Tekavčič, M., Peljhan, D., Marc, M., Schweiger, H., Dolenšek, J., Švigelj, M., Setnikar-Cankar, S. \& Fabjančič, Z. (2002). Strategija razvoja gospodarskih javnih služb v Sloveniji. Ljubljana: Svetovalni center.

Jałocha, B., Krane, H. P., Ekambaram, A., \& Prawelska-Skrzypek, G. (2014). Key competences of public sector project managers. Procedia-Social and Behavioral Sciences, 119, 247-256. doi: 10.1016/j.sbspro.2014.03.029

Jung, C.G. (1946). Psychological Types. New York: Harcourt, Brace and Company. 
Khatri, N., \& Ng, A. (2000). The Role of Intuition in Strategic Decision Making. Human Relations, 53(1), 57-86.

Kohont, A. (2016b). Večplastnost in uporabnost kompetenc. Ljubljana: Fakulteta za družbene vede.

Park, S. M., \& Word, J. (2012). Driven to service: Intrinsic and extrinsic motivation for public and nonprofit managers. Public Personnel Management, 41(4), 705-734. doi: 10.1177/009102601204100407

Rajah, R., Song, Z., \& Arvey, R. (2011). Emotionality and leadership: Taking stock of the past decade of research. The Leadership Quarterly, 22(6), 1107-1119.

Reed-Woodard, M. A. \& Clarke, R. D. (2000). Put some feeling into it: emotional intelligence is paramount in a thriving workplace. Black Enterprise 30, 68-69.

Sadler-Smith, E. \& Shefy, E. (2004). The intuitive executive: Understanding and applying 'gut feeling' in decision making. Academy of Management Executive 18(4), 76-91.

Sadri, G. (2012). Emotional Intelligence and Leadership Development. Public Personnel Management, 41(3), 535-548.

Sanfey, A.G. (2007). Decision Neuroscience: New Directions in Studies of Judgment and Decision Making. Association for Psychological Science, 16(3), 151-155.

Sosik, J. J. \& Megerian, L. E. (1999). Understanding Leader Emotional Intelligence and Perdormance. Group \& Organization Management, 24(3), 367-390.

Taksić, V., Mohorić, T. \& Duran, M. (2009). Emotional skills and competence questionnaire (ESCQ) as a self-report measure of emotional intelligence. Psihološka obzorja, 18(3), 7-21.

Thornton, P. B. (2013). Management - Principles and Practicies. Livermore: WingSpan Press.

Virant, G. (2002). Pravna ureditev javne uprave. Ljubljana: VUŠ.

Wirick D. W. (2009). Public-Sector Project Mangement. Meeting the Challanges and Achieving Results. New Jersey: John Wiley \& Sons.

Zakon o gospodarskih javnih službah (ZGJS). (1993, 2. junij). Uradni list RS št. 32/93.

C. Галич, Громадська комунальна організація «Комунала Новоместо» (Словенія);

C. M. М. Дандан, Ph.D., Північний прикордонний університет (Королівство Саудівська Аравія);

A. Г. Зоран, Ph.D., Департамент організаційних досліджень громадської комунальної організації «Новоместо» (Словенія).

Інтуїтивне прийняття рішень в громадських комунальних організаціях: досвід Словенії

У статті автори досліджують частоту використання інтуїиії менеджерами словенських комунальних організацій у процесі прийняття рішень. При цьому автори зосереджуються на емоційній компетенції, а саме на емоційному інтелекті та інтуїції. Метою статті є визначення статистичної значимості взаємозв'язку між емоційним інтелектом та використанням інтуїиї у процесі прийняття рішень керівниками громадських комунальних організацій. Теоретичну основу дослідження склали результати критичного аналізу наукової літератури за даним напрямом. На основі результатів дослідження автори висунили гіпотези про існування взаємозв'язку між компетенціями, емоційним інтелектом та інтуїцією керівників у процесі прийняття рішень. У ході дослідження було використано метод анкетування та опитано 110 респондентів словенських комунальних організацій. Анкета була розділена на 6блоків, а саме: (1)демограффічні дані, (2)емоційний інтелект (ESCQ), (3) інтуїтивний потенціал, (4) використання інтуїції при прийнятті рішень, (5) інтуїтивний синтез, (6) оточення. При цьому автори наголошують, що аналіз комунальних підприємств повинен проводитися на більшій вибіриі респондентів, що є перспективним напрямом для подальщих досліджень. Результати опитування показали, що більшість респондентів приймають важливі рішення на основі інтуїиії (81,7\%). На основі результатів дослідження автори підтвердили гіпотезу про статистично значимий взаємозв'язок між емоційним інтелектом та використанням інтуїції керівниками у процесі прийняття рішень. При цьому, доведено, що рівень освіти впливає на процес прийняття раціональних рішень - тобто, чим вище рівень освіти, тим більше приймається раціональних рішень без використання інтуїиї. Автори наголошують на тому, що так як дане дослідження проводилося на прикладі комунальних підприємств Словенії, то необхідним є розширення географії дослідження з метою порівняння та врахування культурних особливостей використання інтуїції при прийнятті рішень.

Ключові слова: емоційний інтелект, інтуїція, державне управління, компетенція, компанія, прийняття рішень, успішність.

Manuscript received: 19.10 .2018

(c) The author(s) 2018. This article is published with open access at Sumy State University. 